\title{
Synonym in Malay and Arabic: A Comparative Study in the Aspect of Definition and Importance
}

\author{
Noor Eliza Abdul Rahman ${ }^{1}$, Zulazhan Ab. Halim² \\ ${ }^{1}$ Faculty of Islamic Contemporary Studies, Universiti Sultan Zainal Abidin, Terengganu, Malaysia \\ ${ }^{2}$ Faculty of Languages and Communication, Universiti Sultan Zainal Abidin, Terengganu, Malaysia
}

\begin{abstract}
The study discusses synonym in Malay and Arabic with a general focus on its definition and importance. In addition to that, this study also aims to observe the differences and similarities that exist in both languages when it comes to defining or determining the definition of synonym done by Malay and Arabic scholars and the need of synonyms for both languages and nations. This study is a descriptive literature review that is using contrastive analysis. The result of the study shows that Malay and Arabic differ in selecting the basis for synonyms in the aspect of definition but both languages put 'the similarity in general meaning' as the main criteria in determining two synonymous words. On the other hand, the importance of synonym in Malay and Arabic is not much different. In Arabic, however, the need for synonym seems to be more apparent in the literary field especially in poetry that emphasizes qafiah and verse. On the contrary, the need for synonym in Malay is more significant when it comes to maintaining the manners and politeness in speech.
\end{abstract}

KEYWORDS: Constrastive analysis, Importance, Malay and Arabic, Synonym, Similarity in meaning

\section{INTRODUCTION}

Synonym is one of the linguistic components. It belongs to the semantic field that focuses on the structure of meaning or the relationship between the meanings of words. Synonym is also closely related to the vocabulary development and language enrichment. Malay and Arabic are languages which are seen to progress in expanding their vocabularies. The development of language and the expansion of vocabulary happen due to the need in communication and the scholars' desire to enrich the existing language.

The objective of this study is to identify the definition and importance of synonym in Malay and Arabic, and to make comparison between the two. A study on synonym in the aspect of its definition and importance plays a significant role in the betterment of language and its relationship with the lives of Arabic and Malay communities.

\section{DEFINITION OF SYNONYM}

The study will review the definition of synonym in terms of its literal and technical meaning according to Malay and Arabic scholars. 1. The views of Malay scholars.

The word synonym comes from the English word, synonymy. The word is derived from two Greek words; onoma which means name while syn means with (Mansoer, 1986: 100). According to Tarigan (1985: 17), the word synonym consists of the word $\sin$ which means same or similar and the word onim which means name.

In its technical sense, Raminah and Rahim (1985: 280) have stated, "Synonyms are words in a language that have almost identical meaning. Those words are said to have similar meaning because in reality, a word does not mean exactly the same as another word. For example, the words warm (hangat) and hot (panas). Although both have same meaning, they could not be used exactly in the same place. For instance, we could say hot day (hari panas), but it would be awkward if we say warm day (hari hangat)."

Keris Mas (1990: 35) on the other hand has stated that "Synonyms or synonymous words are words that represent one concept. For example, house, palace, castle, hut and lodge are considered synonyms because each of these words refers to one same concept: residence or accommodation. Whereas words such as sad, despondent, sorrowful and downhearted are said to be synonymous because they represent a concept or idea of some kind.” 


\section{International Journal of Current Science Research and Review}

ISSN: 2581-8341

Volume 04 Issue 12 December 2021

DOI: 10.47191/ijcsrr/V4-i12-29, Impact Factor: 5.825

According to Abdullah (1982: 241, 242), "Synonyms are made up of words that have the same meaning though the meaning does not have to be one hundred percent the same. Nevertheless, the application of these words does show enough similarity to conclude that they have same meaning."

Whereas Tarigan (1985: 17) is of the opinion that, "Synonyms refer to words that are grouped together with other words in the same classification based on the general meaning. In other words, synonyms are words that have same central meaning but differ in feeling or value; same denotation but different connotation." Examples are as follows:

a. Smart, intelligent, clever, brilliant

b. Death, deceased, demise, passing, end

c. Stupid, foolish, dumb, dense

d. Beautiful, pretty, attractive, gorgeous, lovely

Based on the discussion above, Abdullah Hassan has presented comprehensible perspective on the definition of synonym meanwhile Keris Mas has made concept as the main condition for words to be considered synonym. However, examples given seem to highlight more its hyponymic relationship between word that has broader meaning (accommodation) and words that contain specific meaning (house, castle, hut). This is because house, castle and hut are physically different objects. Although these objects could be considered as synonyms, there is a gap in its synonymous relationship. Definitions provided by Abdullah, Raminah and Rahim and Tarigan are more intelligible and suitable to describe what is really synonym.

In conclusion, Malay scholars treat the similar general meaning between different words as the key in delineating synonym. They do not necessitate the exact similarity between the words either in terms of meaning or application in the sentence. Similar meaning is in fact the basic part of the equation for synonym. Despite the claims by the scholars that there are no two words that have completely identical meaning, having similar general meaning is enough for two different words to be considered as synonyms.

2. The views of Arabic scholars.

Synonym in Arabic is called تر ادف (taraduf). The word comes from the word ردف (radafa) which means to follow or to obey. In al-

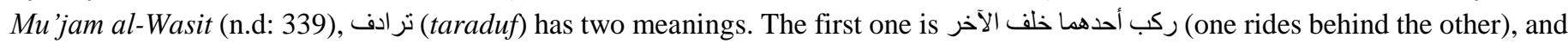

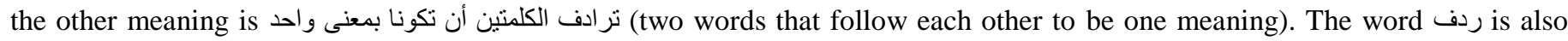
mentioned in al-Quran through surah al-Nazi'at (79: 7): تتبعها الر ادفة (thich means the first blow is followed by the second blow. Technically, taraduf is defined by Ibn Jinni (n.d: 113) as تلاقي المعاني على اختلاف الأصول و المباني (the interconnected meaning beyond the difference in origin and form). Based on the definition stated, Ibn Jinni is of the view that taraduf is similar or shared meaning among words that have different root words. For example, the word خلق الخليقة is derived from the wordaqa) while its synonym which is the word الطبع (taba'a). Nonetheless, both words have the same meaning. Ramadan (1980: 309) meanwhile has defined taraduf as ألفاظ متحدة المعنى وقابلة للتبادل فيما بينها في أي سياق (Some words that have the same meaning and could be substituted in any sentence). Al-Antoki (n.d: 380) is of the opinion that taraduf is الألفلظ المختلفة على المعنى الو احلى (A few different words that point to one meaning).

All definitions above stated by Arabic scholars pinpoint that taraduf is an occurrence of similar meaning between different words. They also do not necessitate that the meaning has to be exactly the same. Ramadan is the only one who requires that the words must be interchangeable in every sentence without any difference in terms of meaning and application. The other scholars on the other hand offer very brief definition of taraduf.

To sum up, different words having similar meaning is considered sufficient to describe the phenomenon of taraduf or synonym. While in actuality, there is no perfect synonym because two synonymous words would still differ whether in terms of their specific meanings, types, contexts or how they are used in the sentence, sharing nearly the same general meaning is enough for the words to be recognized as synonyms.

\section{IMPORTANCE OF SYNONYM}

Synonym plays a crucial role in the vocabulary development of a language. Language is used by humans in their speech which is made up of various lines or sentences. A sentence contains words. This study will explore the significance of synonym in languages specifically Malay and Arabic.

\section{The Importance of Synonym in General}

The importance of synonym could be seen in two aspects which are its significance to the speaker and its significance to the writer. 


\section{International Journal of Current Science Research and Review}

ISSN: 2581-8341

Volume 04 Issue 12 December 2021

DOI: 10.47191/ijcsrr/V4-i12-29, Impact Factor: 5.825

IJCSRR@ 2021

www.ijcsrr.org

1. The importance of synonym to the speaker is as follows:

a. To allow speaker to express the same meaning in various ways.

Ullman (1962: 152) has mentioned that "We always make use of synonyms to avoid repeating the same word for the same idea." For example, the audience tend to feel bored upon hearing same words mentioned few times in a speech. Hence, the speaker needs to diversify their vocabulary by using suitable synonyms to make the speech more interesting consequently garnering the audience's attention.

b. To strengthen a statement.

In some cases, a word must be accompanied by its synonym in order to reinforce the fact or statement mentioned in the speech. In this regard, al-Suyuti (n.d: 406) has stated, قد يكون أحد التر ادفين أجلى من الآخر ، فيكون شرحا للآخر الخفي (Sometimes a word is more clearly defined than its synonym, thus it could explain the latter). Ullman (1962: 153) has further explained, "An important function of such collocations of synonyms is to make one's meaning clearer and more emphatic."

c. To produce the right expression.

Synonym plays a role in creating expressions that are accurate and suitable according to the context and mood (Abdullah, 1982; Yeop Johari, 1987). Malays are particularly known for their courtesy and subtlety in speech. Every spoken word must suit the speaker himself, the listener or the person mentioned and the vibe or atmosphere when the conversation happens. The wrong usage of words could lead to one become a laughingstock or ignite someone's anger. For example, when a student is talking to his teacher, using pronoun $a k u$ and engkau is not exactly appropriate in Malay. This is also applied when discussing stories about Prophet Muhammad PBUH; the most appropriate pronoun to use to mention him would be Baginda.

2. The importance of synonym to the writer and translator.

a. To provide alternative expression that could express one's thoughts.

Synonym is also important to the writer and translator just as well as it is to the speaker. According to Wong (1991: 36), synonym is crucial when a writer is unable to find the right words to express an idea in his mind. For example, when a writer witnesses an event then he wants to incorporate that event in his work, he might feel stuck in choosing words that could portray the event very well. Knowing synonyms could help the writer to restore certain experience or memory quickly when he thirsts for an idea or thought.

b. To choose the rightest words for certain purposes.

Every writer should have a very broad linguistic knowledge and is able to choose the most fitting words to convey his ideas. For journalists in particular, having extensive vocabulary is required in writing a report or article to ensure accurate and effective writing. For the translators on the other hand, synonym is needed to find the similar or exact match in the target language in order to produce honest translation without deviating from the source language. A cruciverbalist also needs to know a lot of synonyms to create or solve crossword puzzles. This is applicable as well to students who are facing written test namely writing long answer or essay. Knowing a great number of synonymous words indeed could help students giving concise yet accurate answers within a short period of time. (Noor Ein, 1992: ix).

\section{The Importance of Synonym in Arabic}

Synonym exists in all languages in this world (Tawfiq, 1980: 240). However, its existence in Arabic is vast to the extent that it is considered as one of the distinctive features of Arabic. Al-Antoki (n.d: 380) has stated that الترادف أمر معروف في كل الألسن ،لا أنه في (Synonym is common in every language but in Arabic, synonym is more widespread than in other languages hence some scholars view it as one of Arabic language's standout features).

Apart from all significances mentioned in the previous section, synonym also has its own importance and role in Arabic. Those are described as follows:

a. To perfect and enhance the artistic techniques in poetry and prose.

Arabs are known for their ingenuity in literature. When it comes to writing poems, there are things that need to be looked out for such as tafilah and end rhyme. Synonymous words are used by the poets to accomplish those artistic techniques subsequently producing excellent literary works. With regard to the use of synonyms in this context, al-Suyuti (n.d: 406) has stated that,

للتر ادف فو ائد: ومنها، التوسع في سلوك طرق الفصاحة، وأساليب البلاغة في النظم والنثر ودللك لأن اللفظ الواحد قد ينأتى باستعماله مع لفظ آخر السجع و القافية والتجنيس

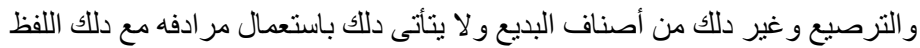




\section{International Journal of Current Science Research and Review}

ISSN: 2581-8341

Volume 04 Issue 12 December 2021

DOI: 10.47191/ijesrr/V4-i12-29, Impact Factor: 5.825

IJCSRR@ 2021

WwW.ijcsrr.org

(Synonym has many benefits. These include enhancing the flow pattern and rhetoric style in poetry and prose. This is because sometimes a word could be matched with another word to fulfil the characteristics of saja', qafiah, tajnis, tarsi' and other techniques when its synonym is not suitable with that another word).

Saja', qafiah, tajnis and tarsi' are among the artistic techniques of Arabic poetry and prose. These techniques require the uniformity of end rhyme and the selection of words that are suitable with the meaning the poets intend to convey. Concerning this matter, Ibn Yacish (in Ramadan, 1980: 323) believes,

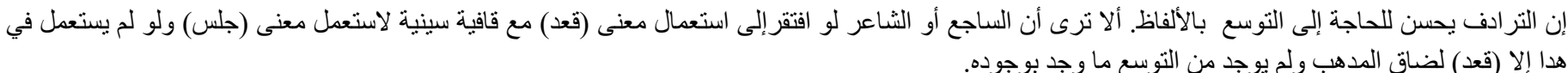

(Synonym is needed to expand vocabulary. Do you not see the badi' and poets? If they have to use word that means and has final

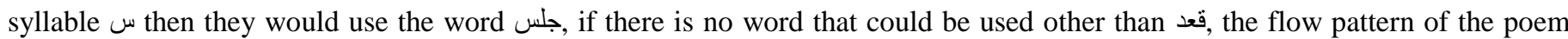
surely would be disrupted and there would be no vocabulary expansion as expansion because of synonym.

Both scholars above have agreed that synonym plays a crucial role in enhancing the rhetoric and artistic elements in poetry and prose. This could be further seen in lines of poem written by al-Jarim (1935: 310):

ما أبعد ما فات وما أقرب ما هو آت

(How far the passing moments are and how close the forthcoming moments are

How far moments that have gone by and how close moments that are to come)

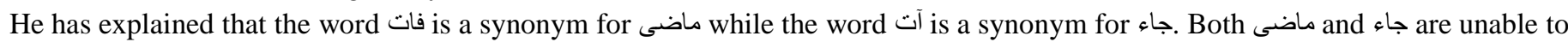
fulfil saja', so their synonyms are used in the poem in order to unify and establish the end rhyme. The same goes for the following lines:

اششتر الُُبرُ و أنفقه في البِر

(Buy grains and donate them for good)

If the poem uses the synonyms of البِّر الخير and الحنطة and الخبر and then the tajnis features or its artistic elements will disappear (al-Jarim, 1935: 310).

Synonym is indeed useful for the literary scholars when it comes to perfecting the rhetorical features in a poem. Not only that the poets need to find the suitable words that could realize the meaning they wish to convey, the words chosen must also have the right artistic elements as well as accomplish the characteristics of personification and the end rhyme along with other words consequently creating outstanding perfect writing. It could be seen here then that synonym plays a vital role in ensuring the exceptional Arabic poetry and its amazing qualities are maintained to this day.

b. To conceal lisp or tongue ties.

There are times where the human tongue is unable to articulate a word properly. This kind of disfluency could bring shame to the speaker, especially if it happens to a leader. In these cases, synonym is necessary to cover the speech impediment subsequently avoiding the shame. Al-Suyuti (n.d: 406) mentions,

"للنر ادف فو ائدها، منها: أن تكثر الوسائلـ أي الطرق إلى الإخبار عما في النفس، فإنه ربما نسى أحد اللفظين أو عسر عليه النطق بها، وقد كان بعض الأذكياء في الزمن

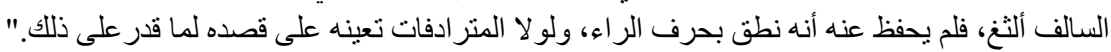

(Synonym has many benefits such as increasing the ways to convey what is in the soul. At times one might fail to remember or pronounce certain words. There were some scholars from olden days who are speaking with a lisp and having difficulty in articulating the letter $\mathrm{J}$. If there were no synonym that could replace the word, they would not have been able to deliver what they wish to convey).

Al-Suyuti has stated above how synonym could solve the lisp or disfluency caused by the tongue and his statement is further supported by Tawfiq (1980: 245) who is in the view of,

ويستر التر ادف العيوب اللسانية, وما حكى عن الخطيب المصقع، واصل بن عطاء، مشهور غير منكور، وقد كان لا يحسن نطق الر اء فخلت خطبتهـالتي ذم فيها بشار -من

(Synonym could cover the restricted motion of tongue. The story of a powerful speaker named Wasil bin 'Ata' is notable and beyond dispute. He is unable to pronounce the letter $\lrcorner$ distinctly making his speech intended to mock Bashar becomes unclear).

The story of Wasil bin 'Ata' is also mentioned by al-Mubarrid (n.d: 106),

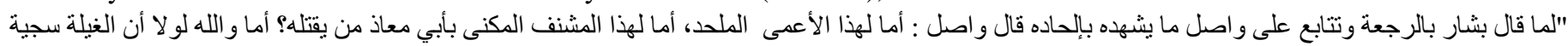

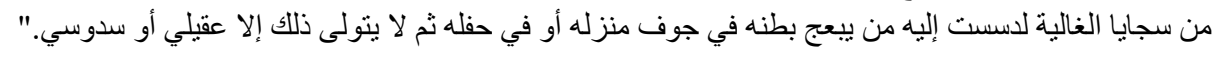




\title{
International Journal of Current Science Research and Review
}

\author{
ISSN: 2581-8341
}

Volume 04 Issue 12 December 2021

DOI: 10.47191/ijesrr/V4-i12-29, Impact Factor: 5.825

IJCSRR@ 2021

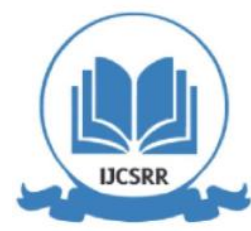

www.ijcsrr.org

(When Bashar talked about the nirvana life and things that proved his infidelity, it always reached Wasil's ears. Wasil then said, "As for this blind infidel foe who wears earing and is called $\mathrm{Abu} \mathrm{Mucaz}$, who will kill him? In the name of Allah, since killing is among the acts of transgressors, I will discreetly send someone to pierce his stomach in his house or at event he attends. The task will be performed by the tribe of Uqail and Sadus.").

In his statement above, Wasil uses the word أبو معاذ as a substitute for بشار and the word المشنف the replace the word that becomes

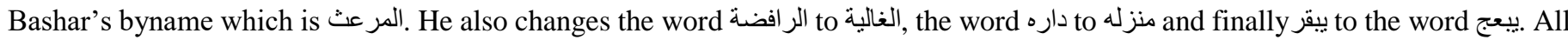
these word replacements show that Wasil is trying to avoid saying words that contain the letter J. Tawfiq (1980: 345) has also come up with a poem praising Wasil's action,

(He (Wasil) uses the word القمح in place of the word البر in expression

$$
\text { ولم يطق مطر البر قحا في تصرفه }
$$$$
\text { وجاذ بالغيث الر اءثفاقى احتال للشعر المطر }
$$

And he avoids the letter $\lrcorner$ so he could speak poetry

And he is unable to pronounce المطر unless the situation urges him

Then he uses the word الغيث to evade the word المطر )

The poem above tells of Wasil's inability to articulate the letter $\lrcorner$ and his cleverness in exchanging the words containing the letter \lrcorner with their synonyms.

Based on the stories presented, it could be concluded that the inability to pronounce a certain word properly could humiliate the speaker specifically the leaders and Arabic poets. The synonym's role in concealing one's lisp or speech impediment seems to be very apparent. Although such problems do exist in other languages, the wide breadth of vocabulary in Arabic makes the role of synonym bigger and more important when it comes to solving the problems concerning lisp or other speech defect.

c. To show contrasting effects between two synonymous words.

The existence of synonym in Arabic is extensive to the extent that it covers the whole sense of meaning. Although two synonymous words have same general meaning, each could have specific or more detailed meaning that makes both words bring about different effect. Hilal (1986: 296) has explained,

من المتر ادفات ألفاظ تبدو فيها خاصة لغوية رائعة هي إظهار ألوان معاني وظلالها وهذه ميزة تكاد تنفرد بها اللغة العربية. (Among the synonyms is a word that has an interesting specialty of expressing various meanings and what are implied behind those meanings. This kind of attribute is almost exclusively in Arabic only.)

This statement is supported by al-'CUrayyan (1991: 401) whose opinion,

$$
\text { لا ريب أن الألفاظ المنز ادفة تلعب دور ا كبير ا في تحسين المعنى وتزيينه وإحداث خصوصية فيه، فقد يكون لإحداهما نأثير لا يكون للأخرى. }
$$

(There is no doubt that synonym plays a huge role in enhancing meaning and creating specialty in it because one word has different effect than the other.)

The effect difference between two synonymous words could be seen through the meaning and representation brought by the word and its synonyms which are الهيام all these words denote thirsty. However, each word signifies different stages of thirst. أنت تعطش means you feel the need for water. When the stage of thirst increases, the word used would be تنت النت أنظام indicates another higher stage of thirst and as the stage rises, أنت تصدى is mentioned. When the thirst is said to be تصئ is means that the thirst level has reached its peak (Hilal, 1986: 297).

Based on the difference between those synonymous words above, it could be understood the degree to which one needs water is different. If فلان عانشان is said, it signifies that one needs only a small amount of water. However, if it is said to be إنه هائع, it could be perceived that one is very thirsty to the extent that he is dying (Hilal, 1986: 298).

The use of synonym to show the effect difference also exists in Malay language and this could be seen through the existence of synonyms for pronouns. The synonyms for the first pronoun are saya, aku, beta and patik. The synonyms for the second pronoun are awak, engkau, anda and kamu while the synonyms for the third pronoun are dia, ia, beliau, mereka dan baginda. The word saya is considered as 'refined language' which reflects the sense of politeness in speech. Aku, awak, kamu, engkau and dia on the other hand are part of colloquial language hence often used in casual setting, and beta, patik and baginda are the language of the palace. The words anda, beliau and mereka are formal terms and the pronoun ia is used to denote non-humans (Abdullah \& Ainon, 1994: 121). Moreover, Malay words that convey the difference between hungry and starving are lapar and kebuluran, respectively. 


\section{International Journal of Current Science Research and Review}

ISSN: 2581-8341

Volume 04 Issue 12 December 2021

DOI: 10.47191/ijcsrr/V4-i12-29, Impact Factor: 5.825

\section{ASPECTS OF DIFFERENCES AND SIMILARITIES}

After the discussion on the definition and importance of synonym in Malay and Arabic, this study has found the differences and similarities between these two languages.

a. Aspect of differences

1. In Malay, the scholars use the word synonym to indicate the similarity of meaning between two different words. The word synonym is derived from English and the root words are sin and onim which means similar or same or with and also onim or onama which means similar.

In Arabic, the term taraduf is used to explain the same. Taraduf comes from the root word ردف denoting to follow or to trail or to ride. Here it could be seen the difference between these two languages in which Malay chooses word that signifies similarity or sameness to show the occurrence of similar meaning between two different words. Arabic, however, uses the word that means to follow, trail or ride to refer to the similar occurrence.

2. The importance of synonym in both languages initially does not differ much. In Arabic, however, the need for synonym seems to be more apparent in literature and this could be seen in the poem arrangement that put emphasis on qafiah and tafilah. Not only an Arabic poet has to consider the end rhyme (qafiah) but the flow and rhyme on tafcilah must also be taken into account. When it comes to meaning, the implicit meaning contained in the poem is often more unique than the straightforward meaning as it uses figurative language and is built upon the poet's imagination (al-Tunji, 1993: 50). Therefore, a poet requires synonym to produce amazing work.

Malay has its own literary value. There are many forms of poetry in Malay such as pantun, syair, gurindam and seloka. Just like Arabic poetry, a Malay poem also prioritizes end rhyme. In pantun, for example, the end rhyme is usually alternating and follows $\mathrm{ABAB}$ scheme for a four-line stanza (quatrain), $\mathrm{ABC} \mathrm{ABC}$ scheme for a six-line stanza (sestet) and $\mathrm{ABCD} A B C D$ scheme for an eight-line stanza (octave). There are also poems that one same-sounding final syllable for each line making it AAAA rhyme scheme (Mohd Taib, 1975: 2). Apart from alternating end rhyme, Malay poem also consists of two parts:

a. Foreshadowed meaning: It is considered as the 'skin' of the poem and is intended to attract the readers' attention to the actual message.

b. Meaning: The actual message the poem intends to convey.

3. During the process of composing poem, the content or the real meaning must be decided first. After that, the 'skin' or the body of the poem could be composed. Between the body and the meaning, there is no required connection between the two because the body is just the opening (skin) of the poem. It does not imply anything apart from the stated meaning (Za'ba, 1965: 224).

As a matter of fact, both languages own literary value that becomes the pride of respective nation. However, the development of Arabic poetry is more intricate compared to Malay poetry. When it comes to writing a Malay poem, one only has to choose words that could complete the body, meaning and end rhyme of the poem. The correspondence of letters is emphasized only at the end rhyme. Hence, the word choice is not a major issue to the extent that it requires extensive number of synonyms. In Arabic poetry meanwhile, the word choice must complement the qafiah and tafilah and further match with the meaning to be conveyed. This has lead to immense need for synonym among Arabic poets. Thus, it is not suprising that scholars believe synonym is vital for the poets to produce high-quality writings.

4. In respect of the role of synonym in concealing lisp or speech impediment, speech problems are not really noticeable among the Malays, though it could happen to those who speak certain dialects. For instance, Terengganurian and Kelantanese are often unable to pronounce words that end with the letter 'n'when speaking in standard language. However, this does not cause shame to them and it becomes part of their identity that somehow could bring amusement. Accent problem also happens to the non-Malays such Chinese and Indian when they speak in Malay. This is also known as ethnic dialect. For example, Indians often have difficulty in articulating the retroflex sound which is produced by curling up the tongue towards the hard palate. They are also unable to pronounce 'b' and ' $\mathrm{g}$ '. Thus, words such as botak (bald) is pronounced poottaa, bodoh (stupid) becomes pootoo, gila (crazy) turns into kiilaa and gemuk (fat) is uttered as kummu (Teo, 1997 43). Just like Terengganurian and Kelantanese, this does not also humiliate the speaker since it is normal for one to have 


\section{International Journal of Current Science Research and Review}

ISSN: 2581-8341

Volume 04 Issue 12 December 2021

DOI: 10.47191/ijcsrr/V4-i12-29, Impact Factor: 5.825

IJCSRR@ 2021

WWw.ijesrr.org

imperfect pronunciation when speaking in different language due to the fact that the tongue is not used to articulate words from language apart from the native language.

In regard to this matter, most Arabic scholars bring forward the story of Wasil bin ${ }^{\mathrm{c}}$ Ata who uses synonyms to hide his inability to pronounce the letter $\mathrm{J}$. Wasil is a scholar and leader during the time when Arabic language is still new and is not yet influenced by external destructive elements. That time Standard Arabic is widely used by the Arab communities of all places. Wasil has to maintain his status as a leader in front of his followers, hence, he uses synonyms in his speech to cover his lisp.

To conclude, lisp or speech problems are not main factor to the need for synonym in Malay language but considering the story of Wasil, it is the opposite in Arabic. Arabs prioritizes the proper use of language and language proficiency is a symbol of their pride. Therefore, the need for synonym or extensive vocabulary is very prominent among Arabs especially those with high status and title in society.

b. Aspect of similarities

1. The similarity in meaning is the starting point for the discussion of synonym in Malay and Arabic. Although there are other conditions for a word to be recognized as synonym such as the accuracy of meaning between the words and the interchangeability of the words in accordance with context sentence. The existence of similarity in general meaning is sufficient enough to recognize two words are synonymous. Scholars of both languages also believe that the similarity in meaning does not necessarily mean the words must have completely identical meaning. Instead, the synonym denotes the shared general meaning between words with different forms.

Malay and Arabic respectively need synonym in order to enrich vocabulary. In both languages, synonym plays a role in helping speakers and writers to fulfil the following need and interest: to deliver the implicit meaning clearly, to convey the same meaning in various ways without repeating the same words, to strengthen a statement and to find the right and suitable expression according to the context and environment.

\section{RESEARCH FINDINGS}

This study has discussed 'the similarity in meaning' contained in the synonym. The outcome shows that the similarity in meaning does not mean one hundred percent the same or in other words, the similarity in meaning between synonymous words is by no means absolute. This is because each word has its own characteristics of meaning that other words do not have.

This study has also shown that synonym plays an important role in aiding speech and writing in any language. However, synonym's role in Arabic is more evident during the process of composing poetry and as an effort to conceal speech problems. Arabs' dedication in enriching their language leads to the expansive vocabulary or synonym that comprises the general and specified meanings and also explains the degree of certain features. Compared to Malay nonetheless, synonyms in Arabic that exhibit emotional values that further distinguish its usage between different groups are only a few.

As for Malay language, efforts in increasing synonyms that could signify the different degree of one nature or condition need to be improved. In addition to borrowing process, steps to explore dialects and syllables have been taken to increase the number of synonyms and to fulfil the meaning interest. Not only this could enrich Malay language but could also ease the conveyance of meaning promptly.

In summary, Malay and Arabic languages require synonyms to enhance the vocabularies. In spite of that, synonym is much more widespread in Arabic than Malay to the extent that it is considered as the splendor of the Arabs subsequently becoming one of the developmental factors of Arabic language.

\section{REFERENCES}

1. Lashin 'Abd alFattah. (1983). Safa' al-kalimah.al-Riyad: Dar al-Marikh.

2. Hilal ${ }^{\mathrm{A}} \mathrm{Abd}$ al-Ghaffar Hamid. (1986). Ilm al-lughah bayna al-qadim wa al-hadith. Kaherah: Matbacah al-Jablawi.

3. Abdullah Hassan. (1982). Linguistik am untuk guru bahasa Malaysia. Kuala Lumpur: Fajar Bakti.

4. Abdullah Hassan \& Ainon Mohd. (1994). Tatabahasa dinamika. Kuala Lumpur: Utusan Publications Distributors Sdn.Bhd.

5. Ahmad Mukhtar Umar. (1982). Ilm al-dalalah. Kuwait: Dar al-Buhuth al-Ilmiyah.

6. Al-Mubarrid, Abu al-Abbas Muhammad bin Yazid. (n.d). al-Kamil. Beirut: Dar al-Fikr. 


\section{International Journal of Current Science Research and Review}

ISSN: 2581-8341

Volume 04 Issue 12 December 2021

DOI: 10.47191/ijesrr/V4-i12-29, Impact Factor: 5.825

IJCSRR@ 2021

Www.ijcsrr.org

7. Tawfiq Muhammad Shahin. (1980). Al Mushtarak al-lughawi: nazariyyat wa tatbiqat. Kaherah: Maktabah Wahbah.

8. Al-Jarim Ali. 1935. Al-Taraduf. Majallat majma' al-lughah al-Arabiyyah, Oktober. 303-331.

9. Al-Suyuti, ${ }^{c}$ Abd al-Rahman Jalal al-Din. (n.d). al-Muzhir fi ulum al-lughah wa anwa 'iha. Kaherah: Dar al-Turath.

10. Ramadan Abd al-Tawwab. (1980). Fusul fi fiqh al-lughah. Kaherah: Maktabah al-Khanji.

11. Raminah Sabran \& Rahim Syan. (1985). Kajian bahasa untuk pelatih maktab perguruan. Petaling Jaya: Fajar Bakti.

12. Al-Urayyan, Muhammad Abd al-Hafiz. (1991). Lahjat al-Arab: dirasat tahliliyyah. Kaherah: Maktabat Abna' Wahbah Hasan.

13. Wong Khek Seng. (1991). Tesaurus: Penggunaan dan kegunaannya. Pelita Bahasa, Feb: 36.

14. Yeop Johari Yaakob. (1987). Liku-liku bahasa Malaysia. Petaling Jaya: International Book Service.

15. Noor Ein M. Nor. (1992). Tesaurus bahasa Melayu. Singapura: Times Books International.

16. Al-Sakkakini, Khalil. (1995). Al-Taraduf. Majallat majma al-lughah al-Arabiyyah, 124-130.

17. Ullman S. (1962). Semantics: An introduction to the science of meaning. Oxford: Blackwell.

Cite this Article: Noor Eliza Abdul Rahman, Zulazhan Ab. Halim (2021). Synonym in Malay and Arabic: A Comparative Study in the Aspect of Definition and Importance. International Journal of Current Science Research and Review, 4(12), $1842-1849$ 